\title{
Territórios chamados desejo: Da largueza dos conceitos à contenção das experiências
}

Territories called desire: from the breadth of concepts to the curbing of experiences

Territoires nommés désir : de la largesse des concepts à la contention des expériences

Daniel Francisco

\section{OpenEdition}

\section{Journals}

Edição electrónica

URL: http://journals.openedition.org/rccs/797

DOI: $10.4000 /$ rccs. 797

ISSN: 2182-7435

\section{Editora}

Centro de Estudos Sociais da Universidade de Coimbra

Edição impressa

Data de publição: 1 Junho 2007

Paginação: 165-199

ISSN: 0254-1106

Refêrencia eletrónica

Daniel Francisco, «Territórios chamados desejo: Da largueza dos conceitos à contenção das experiências », Revista Crítica de Ciências Sociais [Online], 77 | 2007, colocado online no dia 01 outubro 2012, criado a 03 maio 2019. URL : http://journals.openedition.org/rccs/797 ; DOI : 10.4000/rccs.797

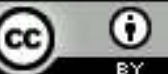




\section{Territórios chamados desejo: Da largueza dos conceitos à contenção das experiências'}

Variadas razões têm contribuído para focar o olhar das ciências sociais nas dinâmicas ligadas ao território. Desde logo, pela relevância que os temas do poder, do desenvolvimento e da coesão social assumem nessas dinâmicas. Neste artigo, aborda-se a forma como os contextos territoriais têm vindo a incorporar as concepções recentes sobre o poder e o Estado, discutindo-se em que medida tal se deve à emergência de formas novas de fazer política a partir dos territórios ou, pelo contrário, serve mais para ilustrar, à escala "local", modalidades de acção suficientemente conhecidas e pouco inovadoras.

\section{Introdução}

A importância atribuída nas últimas décadas aos cenários territoriais, isto é, aos espaços infra-nacionais, para abordar as problemáticas das ciências sociais, explica-se, entre outros factores, pelas circunstâncias que enfraqueceram, desde pelo menos os anos sessenta do século XX, o predomínio das autoridades e das funções "centrais" sobre a "periferia". Desenhando novas formas de organização política e um novo rosto para o Estado, tais circunstâncias retiraram ao esquema centro-periferia a pertinência que lhe era atribuída, à medida que o "centro", suas tutelas e elites viam diminuídas as funções de ordenação maximalista da periferia que lhe tinham sido outorgadas. ${ }^{2}$

\footnotetext{
${ }^{1} \mathrm{O}$ artigo beneficiou da reflexão feita no âmbito do projecto "Territórios Europeus em Perspectiva Comparada" (POCTI/SOC/46778/2002), financiado pela Fundação para a Ciência e a Tecnologia.

${ }^{2}$ Lembra Fernando Ruivo que "os tradicionais centros situados à escala do Estado-Nação parecem ter vindo a sofrer um processo de debilitação no que concerne a determinados dos seus poderes, vendo parte dos controlos, funções e orientações que auferiam serem desviados para outros eixos ou sedes" (2000: 13).
} 
Foram anos de transformações decisivas. Deles emergiram a crise do Estado e o esgotamento do fordismo, as lógicas de "destotalização"3 (Bayart, 1985) e o declínio das pirâmides decisórias tradicionais, as actuações em "rede" e a sobreposição das práticas de "governação" à determinação governamental dos agentes e sectores na sociedade. Enfim, os fluxos contraditórios da globalização e o capitalismo "flexível", que modificaram o perfil socioeconómico das nossas sociedades e suscitaram revisão considerável dos princípios de análise social. Neste campo, as versões da "estruturação" (Giddens), do individualismo metodológico e, no campo da ciência política, do neo-institucionalismo sociológico (Hall e Taylor, 1997), presentes nas abordagens em termos de "redes", "configuração", "capital social" ou "jogos de actores", relativizaram as anteriores leituras funcionalistas e holísticas dos fenómenos. O objectivo foi aproximar as metodologias aos mundos das crenças, representações, símbolos e valores dos indivíduos, mas também da sua racionalidade "em acção", na apropriação pragmática das situações. O que conferiu aos territórios importância inusitada porque quadros privilegiados de formação de culturas e gestão de interesses, mobilização de redes e execução de projectos, acção estratégica e regulação institucional, ou seja, de confronto e compromisso entre versões distintas do poder e do desenvolvimento.

Numa visão mais situada dos processos, o interesse passou a recair na forma como a condição histórico-geográfica dos fenómenos os particulariza e complexifica. ${ }^{4}$ Determinismos de ordem sistémica, imperativos funcionais, preceitos abstractos de avaliação dos factos, foram desvalorizados. Em seu lugar, emergiu a atenção ao vivido, experimentado e imaginado da realidade, lá onde adquire sentido para os indivíduos e é reconfigurada na sua dimensão mais formal ou universal. Mostrando-se como cada sociedade procede a uma construção própria do económico e do político, deu-se relevo às configurações específicas de actores, às normas, instituições ou lideranças emergentes a partir dos territórios. A ideia é que tão importante como as estruturas e as racionalidades que sobrepujam os espaços são os mundos vividos, as trajectórias biográficas, a memória colectiva, as redes relacionais, as instituições e lideranças neles enraizadas, isto é, as experiências e mundos

\footnotetext{
3 Práticas sociais e políticas da sociedade civil que a levam a subtrair-se à dominação do campo social pelo Estado. Para o autor, os "avanços da sociedade civil" criam uma dinâmica complexa e ambivalente entre o Estado e a sociedade, que põe de parte a visão dualista, dicotómica ou binária destas realidades, habitualmente ligada à ideia do controlo da sociedade civil por parte do Estado.

${ }^{4}$ A relação centro/periferia, em especial, foi abordada a partir do rol diverso de elementos - económicos, políticos, culturais, psicológicos - que interagem para a sua estruturação e a tornam pluridimensional, marcada pelas variantes de cada caso.
} 
concretos que vêm ao de cima sempre que se vê as construções humanas na sua especificidade. ${ }^{5}$

\section{O território e as transformações do Estado}

Para se compreender o relevo ganho pelas lógicas territoriais, é necessário ir às mudanças que afectaram a acção pública nas décadas mais recentes. É que, se houve tempo em que o Estado geriu sociedade e território apoiado numa economia industrial em expansão, na integração das elites periféricas no sistema político e em intermediários com monopólios de representação a nível nacional ou sectorial (partidos, sindicatos, associações patronais, igrejas), a partir de certa altura, os equilíbrios socioterritoriais promovidos pelo centro, a condução dos interesses locais pelas prioridades governamentais, os sistemas de mediação corporativa organizados a partir do Estado, viram-se ineficazes e carentes de legitimidade. Uma espécie de "pós-dirigismo" se instalou, dificultando a integração hierárquica dos actores sociais e a antecipação do Estado relativamente aos problemas e dinâmicas da sociedade.

$\mathrm{Na}$ prática, a crise do programa keynesiano e a ruptura das finanças públicas encurtaram logo as margens da intervenção estatal. Os programas de ajustamento estrutural, nos países em desenvolvimento, e as imposições de contenção orçamental, na Europa, repercutindo na dificuldade dos governos para continuarem a assegurar o pleno emprego nas diversas regiões, deixaram muitos territórios desamparados e dependentes, quanto ao seu futuro, de inserção favorável nos mercados globais. ${ }^{6}$ As pressões duma economia competitiva, baseada na inovação e no conhecimento, conjugadas com as dificuldades do Estado para perpetuar os mecanismos correctores das assimetrias territoriais, passaram a moldar o horizonte de cidades e regiões, introduzindo em força a ideia de concorrência interterritorial.

O paradigma do desenvolvimento local substituía-se ao planeamento centralizado. O desenvolvimento a partir de "baixo" punha em relevo as funcionalidades e os recursos endógenos dos territórios. O papel das convenções e das instituições, públicas e privadas, bem como a importância

\footnotetext{
${ }^{5}$ Reconheceu-se que a expressão "local" dos factos os remete para uma cartografia particular, a das variações contextuais. Que é nos universos localizados e específicos que os actores adquirem o sentido pragmático do económico, jurídico ou político, "jogando sobre a variação das escalas de espaço e tempo e libertando-se da tutela constrangedora de modelos pré-estabelecidos" (Cefaï, 2001: 16).

${ }^{6} \mathrm{O}$ tempo em que o Estado, negociando com os grupos industriais, orientava os empregos para as zonas em dificuldade, equilibrando o território, findou: "a crise passou por aí. E o crescimento que retomou, difuso e principalmente com base em empregos do terciário, não oferece o mesmo ponto de apoio às políticas públicas" (Veltz, 2002: 10).
} 
das redes de actores territoriais, passava a explicar o grau de sucesso com que os tecidos económicos de países e regiões participavam nos fluxos globais. ${ }^{7}$ À geografia dos "custos" e dos "stocks de factores" sucedia a das "organizações" e da qualidade das instituições (Veltz, 2002: 12), numa economia mundial onde passavam a estar em concorrência, não apenas produtos, mas modos de organização da sociedade e sistemas sociais (Pecqueur, 2000).

Sem dúvida, a profusão de análises pelo "territorial" trouxe múltiplas teorizações do território, que o tornaram problemático e fluído. Entendido ora como história e cultura enraizadas num espaço, ora como mera resposta a oportunidades "externas" (no sentido de construído por redes que o activam em determinado momento, em função de estratégias específicas e pensando em certos interlocutores), o território pode também ser visto como o quadro jurisdicional de uma entidade concreta (os municípios, as regiões administrativas, as comunidades urbanas ou metropolitanas), o espaço de articulação funcional de certas lógicas e poderes (bacias de emprego, áreas metropolitanas), ou simples matéria flutuante, instável, virtual. Certo é que a "nova economia política" e a sociologia económica mostraram que as economias saíram da crise dos modelos keynesianos apoiadas em factores institucionais e culturais de carácter local e nacional, o que conferiu ao território alguma substância na análise - enquanto espaço de decisão e produção, de cultura e mercado, de redes e instituições. Salientando embora as múltiplas vias para o desenvolvimento, estas abordagens consideram-no essencialmente fruto de dinâmicas territorialmente situadas. Isto é, revelador de profunda "dependência contextual", ancorado nas realidades sociais, políticas e culturais vigentes em determinados espaços. Ocorrerão, pois, os processos de desenvolvimento em espaços onde alguma eficácia colectiva desponte a partir de características maioritariamente endógenas e partilhadas. ${ }^{8}$

\footnotetext{
${ }^{7}$ Da conjugação de factores culturais e institucionais, de memória colectiva e regulações políticas, que explicam os desempenhos a nível territorial, nasceram apreciações que encaram os territórios, por exemplo, como espaços de intermediação de múltiplas trajectórias, alimentando-se "de múltiplos genes que permitirão ou não uma certa dinâmica, uma coesão, uma tomada de consciência e de poder" (Lacour, 1996: 35).

${ }^{8}$ Neste sentido, a materialização das actividades no espaço, a paisagem económica, pode ser "a primeira das formas de regulação" (Benko e Lipietz, 1994: 247). Mas o território, mais do que isso, será fonte genealógica de processos, nomeadamente de coordenação de actores, que nele encontram vocabulários, lógicas, poderes e utensílios com que prosseguem objectivos e concretizam propósitos (Reis, 2006). Os comportamentos relacionais e as práticas cognitivas que a proximidade desencadeia serão então decisivos na génese dos processos. E o território é crucial, não só no comportamento económico, como na "matriz de relações que define a morfologia do poder nas sociedades contemporâneas” (ibid.: 7).
} 


\subsection{Emergência da "governação"}

Para a análise do poder, o interesse pelo território decorre também das mudanças que ultimamente reconfiguraram o Estado e as sociedades nacionais. Se quisermos, as exigências das autoridades locais para gerirem partes maiores da vida dos territórios, que hoje vemos por todo o lado, não são indiferentes à territorialização diferenciadora na economia, nem às mudanças sociopolíticas que a acompanharam. Destacaremos, entre estas, os ataques à gestão centralizada dos problemas e os défices de governabilidade atribuídos a sistemas sociais complexos e fragmentados (Luhmann, 1999); a crise da representação democrática dos cidadãos e das mediações políticas em geral; a descrença nas ideologias, nos políticos e nos aparelhos centrais de regulação social, considerados longínquos, lentos e pesados, prisioneiros de burocracias paralisantes e de redes de interesse que os manipulam; a anemia dos laços sociais e a erosão das protecções institucionais da cidadania (Dubet, 2002); o incremento dos individualismos e das atitudes de "passageiro clandestino" (Olson) dos cidadãos face às políticas públicas. Tudo confluindo numa crise do Estado e das nações como os concebemos.

Estes factores, actuando sobre os sectores públicos e suas políticas, criaram-lhes especial turbulência nas últimas décadas. Traduzem não só o desaparecimento do mundo das orientações claras do pós-guerra, ${ }^{9}$ roubando aos Estados capacidade de pilotagem da sociedade, mas também o agravamento das falhas, défices e incongruências na própria governação (Mayntz, 1993), que ampliou as dificuldades das entidades públicas para regulamentar e impor a sua legitimidade aos grupos sociais. ${ }^{10} \mathrm{Na}$ prática, à medida que a relação entre meios e fins da acção pública mostrava desacertos sucessivos, a pressão para a "libertação" da capacidade auto-reguladora da sociedade redobrava, sobrevindo a resistência de muitos sectores à figura do Estado. Grupos e redes empenhados em actuar sobre as políticas públicas fizeram-se então sentir, desfazendo monopólios estatais e preconizando a condução do público a partir do privado.

Para o facilitar, transferem-se os princípios da micro-economia capitalista para o interior do Estado, com o new public management a promover uma lógica de "Estado mínimo", obediente a critérios de competitividade e

\footnotetext{
9 Vigilância dos equilíbrios macroeconómicos, programação do desenvolvimento, organização das interacções societárias

${ }^{10}$ Para Mayntz, as falhas da autoridade pública agrupam-se em "quatro problemas da regulação": incapacidade para fazer vigorar a regulamentação (implementation problem), com a recusa dos grupos sociais, não raro da própria burocracia, de reconhecer a legitimidade dessa regulamentação (motivation problem), fraca ponderação ou avaliação da relação meios/fins (problema das relações de causalidade mal medidas, knowledge problem), falta de competência (jurídica) e de instrumentos de governo (problema institucional, de "qualidade do direito", governability problem).
} 
guiado por redes auto-organizadas (Rhodes, 1997). A migração da gestão empresarial para dentro do Estado significa, nesse aspecto, a tomada da acção pública pelas regras da corporate governance, ${ }^{11}$ incutindo-se como repertório de modernização aquilo que, muitas vezes, não passa da mera assimilação das administrações públicas a entidades de mercado. ${ }^{12}$ No final, a "escolha racional" estende-se a todos os domínios, esbatendo, nomeadamente, as diferenças entre o público e o privado.

\subsection{Governo e "governação"}

Em campo surgiu um feixe heterogéneo de grupos e forças, ligados muitas vezes a redes transnacionais, que colocam problemas sérios de regulação às instâncias públicas. Requerendo ao mesmo tempo satisfação dos seus interesses pelas políticas públicas e mãos livres para gerir a relação com os outros, fazem com que ao espaço teoricamente integrado do Estado e da nação se substitua uma "poliarquia institucional marcada pela confrontação de poderes heterogéneos, pouco previsíveis e dificilmente hierarquizáveis" (Duran e Thoenig, 1996: 580). Isto numa arena política que se "desdiferencia sob a pressão e a multiplicação de grupos de interesse cuja acção interfere com a dos responsáveis políticos ao ponto de lhes quebrar o monopólio de representação e de argumentação".

A capacidade de organização destes grupos remete para os instrumentos especializados, como o direito ou a engenharia, e a mentalidade tecnicista (Santos, 2005: 15) com que se avaliam agora as legitimidades para actuar na esfera pública e gerir as políticas governamentais. Fora de jogo fica o poder coercivo do Estado, que apenas surge como parceiro "desde que participe numa qualidade que não a de Estado soberano e que, ao fazê-lo, assuma, idealmente, um estatuto semelhante aos dos demais parceiros" (ibid.).

\footnotetext{
${ }^{11}$ Forte controlo financeiro da gestão, concorrência entre sectores, redes e serviços públicos pela "clientela", value for money em parcerias ou concorrência com o mercado (visando o lucro, não objectivos político-ideológicos), fim das cadeias e procedimentos hierárquicos, expedientes pragmáticos de cooperações descentralizadas em projectos pontuais, etc.

${ }_{12}$ Em toda a Europa, dispositivos similares de reforma administrativa foram aplicados. De acordo com a filosofia de "aligeiramento" e redução do peso do Estado, introduziu-se gestão empresarial na prestação de serviços públicos, agências executivas autónomas em funções ministeriais, "indicadores de performance", competição e responsabilização nas burocracias tradicionais, para as tornar mais profissionalizadas, móveis e controladas por autoridades independentes, como os Quangos na Grã-Bretanha. A ideia foi privatizar tarefas e liberalizar amplas zonas dos sectores públicos - chegando até a suspender muitas das obrigações do Estado-Providência -, embebendo a paisagem administrativa na nova gestão pública. No final, não só as fronteiras entre o público e o privado perdem sentido, como o sentimento do Estado enquanto "valor supremo de refúgio e garantia" dos modos de vida dos indivíduos, já praticamente desaparecido da Europa Ocidental (Inglehart, 1993), dará lugar à sensação de vazio inerente a um "État-creux" (Leca, 1994, retomando a expressão de Guy Peters).
} 
Em concreto, o Estado é pressionado a permanentes negociações - formais ou informais, previsíveis ou caóticas - com os múltiplos actores que a modernização e a complexidade social disseminaram. Absorvendo funções governativas, estes tornam-se mentores e agentes de políticas públicas, determinando-lhes procedimentos, conteúdos e efeitos sociais. Não raro com poder de veto sobre as decisões, levam a autoridade pública a agir num plano mais horizontal, de forma a mobilizá-los, integrá-los, captar os respectivos recursos ou inserir-se nas suas redes.

Complexas imbricações de actores - entre Estado e sociedade civil, política e administração, centro e periferia - diluem então as fronteiras entre o público e o privado, a decisão e a implementação, os distintos patamares territoriais, falando-se de "governação" em vez de "governo". Em circunstâncias onde a regra é a dispersão das competências necessárias às actuações, bem como a multiplicação dos canais e interdependências entre diferentes níveis de governo, instituições, sectores de actividade, agentes em geral (Kooiman, 1993; Jouve, 1995), a possibilidade de a integração das lógicas dos actores ser feita a partir de qualquer instância única desaparece. Perdendo os seus principais atributos e ferramentas de regulação social, o Estado vê-se sujeito a processos imprevisíveis de confrontação de agentes e redes muito diferentes entre si.

Para a autoridade pública, cada passo tem agora de ser medido, negociado, respeitando a singularidade das situações e admitindo interlocutores com graus de organização, qualificação técnica e exigência crescentes. A governação significa, nesse aspecto, a presença junto da administração pública de intervenientes com lógicas de acção muito diferentes, vindos de uma sociedade dominada por relações de concorrência e que se impõem ao Estado na condução das suas políticas. A tónica é o fim do monopólio dos actores governamentais nos processos de decisão. Também a substituição das práticas hierárquicas de governo por modos de organização mais horizontais, cooperantes e consensuais (entre o público e o privado, o centro e a periferia). Nestas configurações, que implicam o sector privado e os grupos sociais mais dinâmicos, nenhuma organização tem autonomia completa. Mesmo que queira impor um certo controlo, depende de outros. A estrutura das actuações faz-se com dispositivos aparatosos, onde ninguém tem todo o poder, mas todos alguma parcela dele - o que tende a tornar opacos os mecanismos de decisão e problemáticas as atribuições de responsabilidade (Stoker, 1998). Quer dizer, a acção pública desenrola-se num sistema organizacional longe do grau de coerência e acabamento que atribuíamos à máquina governamental. A condução objectiva, linear e instrumental do Estado é dissolvida pelo jogo de actores (públicos, privados, 
associativos) que a envolve a todos os níveis. Interesses e poderes muito diversos condicionam as opções públicas, num cenário onde a fragmentação e o individualismo dos intervenientes, em permanente atitude de "sócios-rivais”, imperam (Gaudin, 1999). Com eles, a autoridade pública não tem outra solução senão negociar.

Ao Estado tira-se pois o papel de autoridade única, deixando-se-lhe o de iniciador, ou animador (Donzelot e Estèbe, 1994), das redes e parceiros relevantes para as funções públicas. O pressuposto é que o modelo estatal, por si só, não tem a agilidade e a eficácia necessárias às performances "operacionais", entravando os impulsos duma sociedade civil "libertada" e das forças "vivas" nos territórios. Hostis a formas de controlo centralizado, estas privilegiam a coordenação "flexível" dos projectos. Isto é, a condução das dinâmicas a partir "de baixo", sem comandos hierárquicos ou burocráticos a tolher o pragmatismo das vontades. Apostando na competência funcional e nas virtudes da gestão, desvalorizam a representação institucional da política, pugnando pela abertura do político ao mercado. A intenção é legitimar aqueles que estão em condições de manusear as políticas públicas por critérios empresariais, as redes multipolares de cooperação e negociação, as relações informais e os arranjos flexíveis das parcerias, sobretudo as que combinam universos sociais distintos.

Donde a transferência de decisões para redes especializadas, que o recurso maciço à instrumentação das políticas públicas tem vindo a confortar (Lascoumes e Le Galès, 2005). Dispositivos de controlo e disciplina, cálculo e medida, avaliação e codificação técnica da "governamentalidade" (Foucault) generalizam-se, acarretando não só a "despolitização" da actividade governativa - as questões da legitimidade e do poder são abandonadas em prol da "resolução de problemas" - como a preeminência de redes de especialistas sem as quais nada parece funcionar. ${ }^{13}$ Integradas por "intimos" ou "parceiros" a quem o estatuto é confirmado pela posse de determinados saberes, interesses convergentes ou um passado comum entre pares, tais redes podem ser dotadas de transparência ou coerência interna. Quer dizer, ser legíveis e participadas a partir de "dentro". No entanto, tendem a revelar-se opacas para o exterior, sem preocupação de transparência, abertura ou codificação compatível com os restantes sectores, redes, público em geral (Papadopoulos, 1995). No limite, as decisões importantes podem cair sob a alçada de tecnocracias impermeáveis ao escrutínio público, seguindo

${ }_{13}$ Lorrain (2004: 165) diz que os eleitos, antes em contacto directo com a realidade, cederam o lugar aos especialistas, tal como nas empresas se fez a passagem dos empresários schumpeterianos aos gestores de Burnham. 
a "tendência para a delegação funcional do debate naqueles têm a reputação de possuir as competências e os saberes modernos" (Gaudin, 1995: 55). Mais comummente, ficam-se pela consulta de agentes escolhidos pela sua condição de especialistas ou portadores de interesses legitimados para intervir nas políticas públicas. Mas sempre, em qualquer caso, reflectem o peso das "ordens locais" (Friedberg, 1993) que os funcionamentos reticulares instauram, fragmentando Estado e sociedade a ponto de se tornarem risco maior para a cidadania e a democracia. Como diz Rouban (1999: 2), "as redes não são necessariamente democráticas e mais facilmente criam comunidades do que cidadãos”.

Não surpreende, por isso, que, nestes universos complexos e instáveis, povoados de agentes competitivos e onde as anteriores "certezas estruturadas" pelas normas do Estado dão lugar a "incertezas não estruturadas" (Duran e Thoenig, 1996), numa anarquia vagamente organizada, se cavem défices profundos na noção do bem comum. É que o "interesse geral" torna-se controverso, à medida que a ideia de um interesse capaz de integrar todos os interesses particulares perde credibilidade. Grupos ou redes autoorganizados intervêm agora no "interesse geral", que condicionam a deliberações com eles negociadas. Fazendo com que entre redes e interesses, dum lado, e instituições normativamente orientadas, do outro, o espaço dos possíveis, as controvérsias e a concorrência se tenham ampliado. Oportunidades de cooperação, convergência de pontos de vista, integração de objectivos entre ambos, público e privado, aparelhos e redes, podem surgir, como propõem as versões optimistas da "governação". Todavia, mais evidentes são as zonas de friç̧ão e confronto. Entendimentos e compromissos aparecem, sem dúvida, mas quase sempre no plano sectorial, sob tensão e à beira do impasse. Nisto autoridades do Estado, forças económicas e entidades associativas se envolvem, numa disputa permanente onde a responsabilidade e a legibilidade públicas tendem a diluir-se. ${ }^{14}$ Daí que as políticas públicas passem a assentar em explicações "de tipo 'comunalização', que insistem na fabricação de compromissos restritos socialmente (a certos grupos) e/ou geograficamente (a certos territórios), em compromissos entre

\footnotetext{
${ }_{14}$ A teoria anglo-saxónica mostrou como na acção pública toda a linearidade pode ser suprimida, tomando os procedimentos uma feição essencialmente "incremental" que os aproxima da "anarquia organizada" (Cohen, March e Olson, 1972) ou do "incrementalismo disjuntivo" do muddlin'through. Isto é, duma prática governativa cujo único objectivo é chegar a ajustamentos mútuos das partes em interacção (Lindblom, 1959). Idas e vindas da administração ao "terreno" para consultar actores, assumir decisões e indecisões, ensaiar improvisações, forjar avanços, sujeitar-se a recuos, contribuem para cingir as funções públicas ao amparo de dinâmicas societais cuja orientação global lhes escapa. Esta vai residir mais no jogo das influências, redes ou poderes estabelecidos no mercado do que numa direcção consciente e politicamente sufragada a dar à sociedade.
} 
níveis de gestão - local, nacional e internacional -, assim como em compromissos selados pela fabricação de referentes comuns ou, dito de outra maneira, sentidos cognitivos partilhados" (Massardier, 2003: 64).

Por outro lado, o recurso maciço a dispositivos técnicos e jurídicos densos, de elevada complexidade, na condução da vida pública, faz com que o poder saia das mãos dos cidadãos, e dos próprios governantes, para ser incorporado em "instrumentos que funcionam como sistemas técnicos independentes dos actores" (Lorrain, 2005: 189). O resultado é a forte restrição do horizonte dos intervenientes na esfera pública, com a perda de sentido e a sensação de "impotência" e mal-estar na actividade política. Frente aos "pilotos automáticos" dos registos especializados (políticos, jurídicos, técnicos), de temporalidades próprias e obedientes a influências por vezes remotas, não só se deixa de ter uma visão de conjunto das coisas, como os grandes princípios da acção pública (justiça social, democracia, bem comum) e a relação pessoal entre eleitos e cidadãos se desvanecem. Interferir nas políticas públicas fica para quem consegue - discreta e estrategicamente, fora do escrutínio público - condicioná-las antes mesmo de verem a luz do dia.

Frágil permanece o desígnio de construir sociedades mais justas e coerentes, que as mudanças em curso na cidadania também atestam. Ao privilegiarem uma vertente económica e social da mesma, transformam partes crescentes da população em produtores-consumidores de serviços sociais. Isto é, prestadores-beneficiários a quem se retira a condição de sujeitos de cidadania política propriamente dita (Schnapper, 1994: 15). Da fragmentação do Estado em políticas e sectores geridos com base na "especialização" decorre pois uma visão igualmente fragmentada do cidadão. Que põe em destaque a condição económica e socialmente avalizada de cada um - a de consumidor de políticas gizadas por especialistas -, e não a de alguém integrado num território, a encarar sob o prisma da sua capacidade política, pertenças ou identidade. ${ }^{15}$

Finalmente, fica do Estado a imagem dum conjunto de forças, organizações ou agências em concorrência permanente, ao jeito dum "agregado compósito de segmentos heterogéneos, cada um com a sua política e racionalidade" (Timsit, 2004:306). A impressão é a de um aparelho fragmentado, pouco guiado pela rigidez burocrática e moldável a interesses diversos, menos autoritário e mais "negociado" (Streeck e Schmitter, 1985; Ruivo,

${ }_{15}$ A tendência é para converter o cidadão na figura "do utilizador, do assistido ou do excluído, outras tantas declinações que respondem ao consumidor ou ao cliente do sector privado" (Pongy, 1997: 123-124). 
1993), cujas partes não funcionam em ordem a um todo coerente. A coordenação das actividades do Estado parece, de facto, feita essencialmente de negociações, rivalidades e alianças internas (Poggi, 1996: 32), segundo lógicas corporativas ou de influência que anulam qualquer noção de conjunto. Mais do que a expressão de uma vontade colectiva, o Estado será um campo de vontades em competição.

\section{3. "Proximidade" e projecção dos territórios enquanto actores}

No quadro do acima exposto, parecerá estranho vir agora falar-se de processos de renovação da acção pública em curso, com referência, concretamente, a realidades sociopolíticas organizadas para uma certa procura do "bem comum", de forma coerente, eficaz e multi-participada, num determinado quadro sócio-institucional. É, porém, o caso quando se põe o olhar na importância que a "proximidade", os "territórios", a subsidiariedade, as parcerias locais, a delegação de competências para "baixo", enfim, a filosofia e a gama de instrumentos dos poderes locais, assumiram na Europa nas últimas décadas. Importância assinalável e virada, declaradamente, para uma opção pelo "local" como factor de revitalização da vida pública. O mesmo é dizer, para o território como novo princípio da acção pública e os poderes locais como veículos da reintegração do particular no geral, ou do indivíduo no colectivo, nessa luta premente por manter "em conjunto as partes do corpo social" (Lorrain, 2000: 39).

Difundido com sucessivos instrumentos, que o materializam e lhe conferem aura de irreversível, o propósito do tratamento descentralizado dos problemas é modernizar a acção pública e renovar a legitimidade dos poderes. E está de facto por detrás de muitos impulsos reformistas nos sistemas políticos europeus das últimas décadas, apostados em recuperar a autoridade governativa, reconciliar os cidadãos com os seus representantes e reconstruir os laços da vida em sociedade. Depositários das virtudes e palco das mediações necessárias à refundação da política, ${ }^{16}$ os contextos de proximidade deverão trazer maior transparência e imputação de responsabilidades às decisões públicas. Igualmente, maior prontidão na reacção da classe dirigente aos problemas das pessoas, satisfação das suas necessidades de identificação territorial e promoção de uma democracia mais participada, aberta à sociedade civil. ${ }^{17}$

\footnotetext{
${ }^{16}$ Mediações entre Estado e sociedade civil, mas também entre os vários sectores e interesses que a proximidade ajudará a descompartimentar.

${ }_{17}$ A "proximidade" tornou-se na fórmula mágica, palavra-totem ou novo fetiche do mundo político (Lefebvre, 2001). A ideia é que "certos processos de acção supõem, para ser eficazes e performantes, relações de implicação recíproca, de troca, de coordenação, de rapidez de gestão e de
} 
Por outro lado, a proximidade responde às solicitações da União Europeia, mobilizada em torno de princípios como a subsidiariedade e a participação, no centro operacional dos seus programas. Nessa linha, também a Europa ajuda ao movimento de "territorialização dos problemas públicos, que não podem ser tratados uniformemente ao nível central e cujas questões têm de ser discernidas e formuladas caso a caso por actores de proximidade" (Mabileau: 1997: 357). ${ }^{18}$

Foi assim que medidas de desconcentração administrativa, primeiro, de descentralização e contratualizações diversas, depois, levaram em vários países a um quadro mais "intergovernamental" entre centros e periferias, pondo num plano mais equilibrado, marcado por maior diálogo e respeito mútuo, relações antes vistas como de simples hierarquia ou dependência dos agentes periféricos face às determinações centrais. ${ }^{19}$

Desta forma, se por um lado o mercado, o individualismo e a complexidade social obrigam o Estado a retrair-se, por outro foram criadas condições para que territórios intermédios, como as cidades e as regiões, pudessem emergir enquanto patamar alternativo de integração de actores, de organização de forças e regulação sociopolítica. ${ }^{20}$ Assegurando focos de governabilidade renovada com as capacidades de reflexão e actuação mobilizadas pelos diversos tipos de actores nos territórios, onde interesses próprios se percebem e formas de acção pública diferentes das do Estado se promovem. Parcerias público-privado, gestão de infra-estruturas envolvendo técnicos,

mobilização de recursos, de flexibilidade e de adaptação para as quais são requeridos relacionamentos de proximidade (no sentido físico e geográfico do termo). Tudo se passa como se o tratamento dos problemas e dos desafios supusesse condições de percepção, de informação e de conhecimento recíproco entre os actores, que não serão viáveis a não ser a uma distância sócio-geográfica aproximada, e que portanto a proximidade é garantia de eficácia" (Lefebvre, 2001: 117-118). ${ }_{18}$ Os autores na senda da multi-level governance salientam a estrutura de oportunidades que a construção europeia abriu às configurações regionais e urbanas de poder. Alargando-lhes o perímetro de actuação e leque de recursos, a Europa converteu-as em actores de pleno direito, tanto no âmbito doméstico como europeu.

19 Que a análise admite nunca terem sido verosímeis, revelando antes a que ponto as "forças" periféricas sempre foram dinâmicas e criativas na tensão dialéctica com o centro (Chevallier, 1978; Ruivo, 2000). Entre centro e periferia existiram sempre circuitos de comunicação e troca que nunca terão sido meros canais para a absorção mecânica, à periferia, das imposições do centro. Pelo contrário, respeitam a trocas, interacções e interdependências, que fazem dos sistemas políticos uma construção dinâmica entre centro e periferia

${ }^{20} \mathrm{Na}$ óptica de Le Galès (1998), os Estados-nação na Europa têm perdido parte da sua capacidade de regulação e estruturação da sociedade, mas outros territórios emergem como lugar de regulação social e política. Precisamente, os territórios infra-nacionais, as cidades e as regiões, níveis possíveis de regulação de interesses, de grupos e de instituições. Diz o autor: "no jogo das recomposições entre Estado, mercado e sociedade civil, que se traduz, nomeadamente, na indefinição das fronteiras, a extensão da lógica do mercado, incluindo na esfera pública, conduz a uma procura de organização política e social noutros planos que não o nacional, nomeadamente em certos territórios" (Le Galès, 1998: 231). 
políticos e beneficiários do serviço público, concertação alargada de pontos de vista e consulta frequente das populações, definição de estratégias para as incertezas da globalização e o recuo da protecção do Estado, tudo isto em quadros de decisão flexíveis, onde objectivos, e meios de os alcançar, possam ser permanentemente inscritos e actores diferenciados possam intervir, parecem constituir os novos moldes da "fabricação" do político visíveis nos territórios.

$\mathrm{Na}$ medida em que organizações ou interesses, públicos e privados, vieram a ganhar, em certos locais, estruturação e coerência, formando configurações de actores animados por programas de acção conjunta, devidamente "territorializados", fala-se mesmo da pujança de novas figuras na cena política - actores colectivos territoriais, de carácter urbano ou regional -, acompanhadas da redefinição das identidades e sentidos colectivos das populações. Em circunstâncias onde a dimensão europeia é fundamental, porque alto lugar de reconhecimento das ambições territoriais (Jeffrey, 1997) e de influência normativa sobre os Estados-membros, no sentido de terem uma atitude favorável à subsidiariedade e às administrações descentralizadas. ${ }^{21}$

A ser assim, as redes de actores, as estratégias e os interesses que interferem nas políticas públicas, apesar do carácter desagregado, policêntrico e até caótico que demonstram, podem assumir alguma coordenação nos cenários territoriais. Do território surgirá uma nova forma de construção do político, sobrepondo, na apreensão e gestão dos problemas colectivos, modos de organização "transversais", "concertados", "cooperativos", "co-produzidos", "híbridos", de interface e sinergia entre actores, serviços e instituições - a semântica territorial é vasta - à exclusividade dos aparelhos Estado e dos sectores profissionais. De maneira mais difusa, reticular ou integrada, equipas de poder de cidades e regiões protagonizarão modalidades de acção estratégica inseridas em dinâmicas de "projecto", lógicas de "contrato", "parcerias público-privado", identidades locais. Levando a que o tratamento sectorial, fragmentado e tecnocrático dos problemas (de exclusão social, desenvolvimento sustentável, transporte colectivo, animação cultural, etc.) tenha em alternativa uma abordagem transversal, global, unificada por um perímetro territorial e obediente a cooperações "pertinentes", dos mesmos. Como escrevem Donzelot e Estebe, "o território liga no concreto aquilo que a sectorialização separa em abstracto” (1994: 22-23).

\footnotetext{
${ }^{21}$ A premissa que preside a este tipo de considerações é a de que o campo de possibilidades, a aprendizagem institucional e os princípios orientadores trazidos pela União Europeia guiam agora as autoridades subnacionais, reforçando-lhes a autoridade e os meios de actuação. A Europa construir-se-á numa ligação frutuosa aos poderes locais, de quem será grande aliada.
} 
Daí que a "governação" tenha sido muito debatida à escala local, quando dos territórios parecem renascer os "sistemas de actores responsabilizáveis por doses substanciais das políticas públicas e pela fabricação de dispositivos comuns de gestão do colectivo" (Duran, 1999: 17). A ideia é que os avanços na descentralização, por um lado, e na construção europeia, por outro, juntando-se às lógicas territoriais na economia, reforçaram as redes de actores e as instituições, as lideranças e estratégias de base territorial, às quais o Estado tem agora de ajustar-se. Porque a acção estatal passou a recorrer a procedimentos contratuais com organizações ou autoridades locais ciosas das suas possibilidades e visões dos problemas (Gaudin, 1999; Marcou et al., 1997), as análises privilegiam estas novas articulações de poder, dando a entender que uma arquitectura político-administrativa inovadora cresce a partir das cidades e regiões. Nela, o Estado não desaparece, antes reencontra razão de ser na instituição e coordenação das capacidades de negociação dos actores no terreno (Durane Thoenig, 1996). Já não fornece tanto o quadro do velho modelo da "regulação cruzada", ${ }^{22}$ nem guarda para si todas capacidades técnicas, políticas ou financeiras necessárias ao progresso, mas passa a mediador decisivo da transição para a acção colectiva no plano territorial. Sabe que, no limite, pode ver-se submerso pelas dinâmicas sócio-territoriais associadas às múltiplas configurações, fluidas e contingentes, que ajuda a criar com os incentivos à cooperação no âmbito das suas políticas (Saez, 1997), mas, não estando em condições de retomar o papel omnipresente e controlador de outrora, que significaria o falhanço da cooperação entre os actores no "terreno", terá de aprender a pensar-se como "Estado em relação", sistema de conjunção de fenómenos que, implicado nas relações sociais, se define essencialmente pelas maneiras com que gere esta implicação.

Já os espaços locais, cidades ou regiões, ganharão nova projecção e solidez interna com o recurso a figuras que não só os eleitos locais na mediação, definição e execução da acção pública, reforçando os respec-

\footnotetext{
${ }^{22} \mathrm{Na}$ França dos anos sessenta e setenta, a "regulação cruzada" descrevia o mundo de interacções, conivências, arranjos políticos e pessoais instalado entre o centro e a periferia, a partir dos hábitos negociais com que figuras do Estado e agentes locais aprenderam a ajustar-se (Worms, 1966; Grémion, 1977). Tratava-se de mostrar os sistemas de acção que uniam a administração central às entidades periféricas, com notáveis locais e responsáveis do Estado profundamente imbricados. Interdependências políticas e pessoais, tecidas do alto da administração aos confins territoriais, formavam a matéria com que as elites periféricas eram integradas nos sistemas político-administrativos nacionais. O cenário era de uma forte centralização do Estado, mas propícia a determinadas formas de poder local e à "domesticação" territorial do jacobinismo (Grémion, 1977). No âmbito local, as práticas clientelares da relação com o Estado reproduziam-se e criavam universos "feudalizantes", de forte personalização dos poderes e cesarismo no estilo político dos autarcas (Ruivo e Francisco, 1998).
} 
tivos sistemas de organização política. Designadamente, a "sociedade civil", chamada a participar nas coligações complexas que, a partir dos territórios, tratam agora da gama difusa de problemas que interpelam as políticas públicas.

\subsection{Aspectos da governação local}

A ciência política, por tudo isto, tem dado grande importância aos formatos da acção colectiva nos territórios. A eles aplica as noções de "troca política" (Négrier e Jouve, 1998), de liderança (Smith e Sorbets, 2003) ou cultura política (Cefaï, 2001). Já há muito, sem dúvida, que trata das "estruturas do poder" (Hunter, 1953), das "coligações de crescimento" (Logan e Molotoch, 1987), dos efeitos do "pós-fordismo" (Harvey, 1992; Jessop, 1994) e da "reestruturação do Estado" (Pickvance e Préteicelle, 1991) nas cidades, em visões de pendor mais neo-marxista. Agora, todavia, evolui para a ilustração dos "regimes urbanos" (Stone, 1989), das parcerias público-privado (Lorrain, 1995), do planeamento e gestão "estratégicos" (Padioleau e Demesteere, 1992; Healey et al., 1997; Bouinot e Bermills, 1995), dos "projectos" (Ingallina, 2001; Pinson, 2005), da "governação" (Harding, 1993; Jouve e Lefèvbre, 1995; Stoker, 1999; Leresche, 2001) e das redes de actores (Novarina, 1997), entre outros tópicos, no contexto urbano. Analisa o capital social e a capacidade política nas regiões (Putnam, 1993; Pasquier, 2004), com interpretações de novo regionalismo (Keating, 1998) ou parâmetros de inovação organizacional (Cooke, 1997). Finalmente, refere-se a "actores colectivos" e ao jogo das identidades, interesses e organizações nos territórios, extraindo daí novas possibilidades para o bem comum (Ascher e Godard, 1999), em vias de renascer como "construção territorial" (Lascoumes e Le Bouhris, 1998).

Apesar das diferentes perspectivas destas noções, um fio de coerência liga as mais popularizadas. Vejamos a de "regime urbano". Forjada a partir dos sistemas de cooperação que juntam, em certas cidades, ${ }^{23}$ actores da economia e da política, do associativismo cultural e do mundo universitário, remete para a possibilidade de alguma coerência e governabilidade "justa" nesses universos complexos e fragmentados que são as metrópoles de hoje. Fala de acção colectiva, convertida em "capacidade de governo", no território, referindo-se, designadamente, aos arranjos, as mais das vezes informais, que levam figuras que muita coisa separa a negociar e a formar objectivos comuns, em ordem aos quais aceitam disponibilizar os recursos diversificados, mas complementares, que detêm.

${ }^{23} \mathrm{O}$ caso de Atlanta, descrito nos trabalhos de Clarence Stone, é exemplar. 
O princípio é que, nos espaços urbanos, podem formar-se coligações de actores diversificados, em lógicas de parceria e acção conjunta que dão a cada cidade capacidade política e considerável autonomia governativa. Por cima de clivagens institucionais, sectoriais ou pessoais, sistemas de cooperação e confiança articularão parceiros muito diferentes. E se a cooperação e a lealdade, não automáticas, têm de deixar que cada um tire benefícios materiais e de curto prazo do "jogo" político, não deixam também de remeter para processos longos de construção e aprendizagem das modalidades de acção mais desejáveis, onde problemas colectivos são tratados com normas, linguagens e procedimentos partilhados, isto é, uma cultura de aproximação e compromisso entre os diferentes segmentos das forças locais.

Aqui, os projectos urbanos, erigidos em objectivo unificador, dão um impulso fundamental. ${ }^{24} \mathrm{E}$ ilustram a utilização alargada que se faz hoje da noção de "projecto", também ela com a sua vertente "territorial" - justamente a do "projecto" como aferidor das potencialidades da acção colectiva nos territórios. ${ }^{25}$

Sobre o "projecto", Calame e Talmant notam que "numa sociedade, o projecto é o que mantém as pessoas de pé. É simultaneamente uma identidade colectiva, a convicção de que é possível sair da impotência, que não é inevitável sofrer passivamente os acontecimentos, enfim é um desejo de sentido colectivo" (1997: 119-120). O projecto acontece quando "numa comunidade humana se ganha consciência de que o que une é superior ao que divide", contando-se com os efeitos de cultura e de consciência do bem público que facilitam "a transformação dum sonho em imaginário colectivo e depois em estratégia” (Calame e Talmant , 1997: 121). De resto, um projecto não é "a execução de operações definidas à partida, mas a aposta na capacidade colectiva de agarrar ou suscitar oportunidades. Um projecto é a constituição de uma inteligência colectiva. Enfim, não há projecto sem estima mútua e sem amizade. Porque o projecto é o elemento central de uma aliança. Elaborar um projecto é participar numa aventura afectiva" (ibid.: 121).

\footnotetext{
${ }^{24}$ Mesmo que os ganhos dos projectos sejam mais para uns do que para outros, favorecendo a elite económica - como muitas análises provam -, é importante a percepção, para os actores no terreno, de que ganhos menores podem, ainda assim, chegar a um grande número.

${ }_{25}$ A análise territorial participa dessa lógica de "projecto" com que hoje se avaliam modos de ser e fazer por todo o lado, como nota Ehrenberg: "as noções de projecto, de motivação, de comunicação são hoje normas. Entraram nos nossos costumes e tornaram-se um hábito ao qual, do topo até à base da hierarquia social, aprendemos a adaptar-nos mais ou menos bem" (2000: 16). Na injunção ao projecto teremos a marca dum tempo "onde a norma já não repousa na culpabilidade e na disciplina, mas na responsabilidade e na iniciativa [...] o indivíduo é confrontado com uma patologia da insuficiência, mais do que com o sofrimento da culpa, com o universo do disfuncionamento, mais do que com o da lei" (ibid.: 16).
} 
Os projectos são, neste entendimento, um meio de criar unidade de acção em sistemas atomizados, suscitando formas de cooperação que de outro modo não ocorreriam. Por outro lado, quando se conjuga, nos territórios, "projecto" e "governação", supõe-se que existe alguma capacidade de autogoverno no âmbito urbano ou regional, agregando forças e interesses de distinta proveniência. Ou seja, não se pensa tanto em termos de "sistemas de acção concreta" (Friedberg, 1993) - mais ou menos voláteis, instituídos por acção externa e mantidos apenas para determinadas iniciativas ou objectivos -, mas numa dinâmica intrínseca aos territórios, que os transmuta em "actores colectivos" com alguma durabilidade. Os territórios aparecem então como contextos "dotados da sua própria agenda, capacidade de acção, modos de regulação: territórios capazes de se representar como sociedades e actores colectivos agindo num contexto de competição territorial" (Pinson, 2002: 234). ${ }^{26}$

Os projectos constituirão um meio de projecção externa dos territórios, a partir das competências "especializadas" que neles podem desenvolver-se (Pinson e Vion, 2000). Mas, tão importante como isso ou mais, organizam a acção colectiva no seu interior. Testando a real devolução de poder aos territórios (a sua passagem de objectos a sujeitos da acção política), aferem a capacidade de cada contexto para produzir as suas próprias coligações e solidariedades - pessoais, institucionais, reticulares -, em torno de consensos operatórios e visões compartilhadas dos interesses territoriais. O "projecto" implica, neste sentido, processos de interacção que reduzem a incerteza, facultando aprendizagens, produção de saberes e decisões colectivas que instauram o território como comunidade actuante. A sua vocação é "afirmar identidades de acção, perpetuar grupos de actores solidarizados pela partilha dos mesmo objectivos" (Pinson, 2004: 201), inscrever no tempo uma forma de sociedade (territorial) que encontra em si valores, energias e soluções de organização para captar oportunidades e adoptar estratégias de valorização dos quadros de vida de todos.

Por isso, afigura-se importante o facto de a cooperação e a legitimação dos actores nos projectos não estarem dependentes ou centradas nas instituições e nos políticos locais. A ideia é que, numa verdadeira dinâmica de "projecto", a cooperação e a confiança recíproca dos participantes emergem de um trabalho de densificação de relações horizontais, produzindo iden-

\footnotetext{
${ }^{26}$ Os projectos exprimem-se, por exemplo, nas operações de política urbana que articulam uma vertente prospectiva e identitária com uma vertente operacional, na forma de grandes operações de transformação urbana e/ou económica que mobilizam múltiplos actores e recursos, segundo métodos de parceria, de negociação sucessiva de objectivos e modos da sua implementação, de interacção entre as diferentes fases dos projectos (Pinson, 2004).
} 
tidades e equipas de acção que instituem o território como espaço político sui generis. No âmbito, bem entendido, da intervenção pública, pois é esta que incentiva e beneficia do facto de que as partes envolvidas na "governação" sintam necessidade de "se referir a uma visão do interesse geral aceitável pelos outros", onde se encaixam os acordos "fundados sobre o projecto de uma obra comum ou sobre a elaboração de fins de interesse comum" (Marcou, 1997: 18).

O "projecto", por conseguinte, faz um inventário dos recursos relacionais, materiais e cognitivos locais, avaliando em que medida são activados na construção de lógicas de acção baseadas em interacções e numa efectiva identidade territorial. À capacidade de se agir em conjunto, que os projectos exprimem nos universos territoriais, devem, pois, corresponder modos de regulação próprios, representações partilhadas do futuro, desafios e controvérsias reconhecidos como importantes, uma certa harmonização cognitiva e a propensão à actuação concertada entre os actores em causa, conferidores dum carácter de sistema cultural e político à cidade. Factor tanto mais importante quanto a competição internacional dos territórios se decide em grande parte na coesão demonstrada pelos seus sistemas de actores - na sua habilidade para construir formas de concertação e entendimento, relações de confiança e consensos acima de divisões partidárias, hierárquicas ou de interesse, contornando os funcionamentos politizados em favor de mobilizações sociais amplas, mergulhadas na sociedade civil e na busca permanente de consensos alargados. Só desta maneira se estabiliza os jogos cooperativos entre os actores, levando-os a descobrir interesses comuns e sentimentos de pertença, a investir no diálogo e nas interdependências, na reciprocidade e na identidade comum, territorializando as respectivas estratégias, mormente económicas. ${ }^{27}$

A "governação" associada a este tipo-ideal de "projecto de território" implica, assim, pela parte das figuras no terreno, a capacidade de obter recursos, partilhar ideias e elaborar consensos para trabalhar em conjunto. Contribui para debater em que medida cada cidade ou região encontra nas suas entidades e figuras representativas meios e vontades - competências, recursos materiais, instrumentos operacionais, predisposição mental, interesse prático - para assumir colectivamente projectos modernizadores: de

\footnotetext{
${ }^{27}$ Tudo aspectos que a instância política não está em condições de assegurar, podendo até prejudicar - "a instituição política revê assim o seu papel. Ela já não é o actor central das mediações e dos processos de legitimação dos actores. A instituição de um território passa, antes, por processos de legitimação dos interesses e dos actores sociais entre si. Como dissemos, a instituição municipal descentra-se para se tornar um agente capaz de reduzir os custos de cooperação e de fixar o quadro territorial das interacções constituintes" (Pinson, 2002: 251).
} 
renovação urbana, transporte e mobilidade, ambientais, científicos, etc. Porque se requer que os projectos aglutinem múltiplos intervenientes e sirvam um propósito colectivo mais ou menos sufragado pelos cidadãos, aponta-se o facto de mobilizarem redes e grupos diversificados nos territórios, num sistema relacional aberto e participado, não imposto pela vontade estrita dos políticos, e que faz o território existir enquanto sujeito político, actor-colectivo territorial.

Donde, finalmente, a noção de "bem comum como construção territorial" (Lascoumes e Le Bourhis, 1998), tanto mais adequada quanto a diferenciação dos palcos das políticas públicas faz apelo a modos de gestão menos estandardizados e mais específicos a cada local. A ideia é a de que será de "fóruns deliberativos" nos territórios que poderão emergir, cada vez mais, as regras para enquadramento dos agentes e intervenções no terreno, criando-se hábitos de trabalho em conjunto que desaguarão na formulação de acordos válidos para o desenvolvimento e a resolução de problemas em cada contexto territorial. Falar de "bem comum" como construção territorial é dizer que o jogo das identidades, interesses e oposições que os actores incarnam nos territórios, traduzido muitas vezes em "torneios" competitivos, pode resolver-se com a aprendizagem mútua proporcionada pelas interaç̧ões, levando a ajustamentos de interesses e à adequação recíproca das identidades dos envolvidos.

$\mathrm{Na}$ verdade, interesses e identidades não são imutáveis. E as oposições suscitarão confrontos que constituem outras tantas oportunidades de troca, passíveis de ensinar a lidar, de forma positiva, com os antagonismos de partida. ${ }^{28}$ Importante é que as divergências sejam objecto de procedimentos de cuja aplicação nasçam novos encadeamentos dos interesses e posições iniciais de cada um, de modo a chegar-se a um interesse geral suficientemente operacional para o território. Argumenta-se, assim, que nos territórios há condições para erigir quadros de ajustamento de identidades e interesses concorrenciais - mesmo sem dispositivos formais, nem objectivos substantivos a determinar, a priori, as interacções -, onde o poder do Estado se resuma, quando muito, à "convocação" dos actores (Calame e Talmant, 1997; Ruivo, 2000b). ${ }^{29}$

A convicção, mais geral, é que o modelo tecnicista em que o sistema político-administrativo se habitou a funcionar será contrabalançado por um modelo deliberativo, marcado pela conjugação permanente de interesses

\footnotetext{
${ }^{28}$ Por exemplo, conduzindo os actores a redes relacionais renovadas com a participação de novos intervenientes, ou a visões alternativas dos problemas.

${ }^{29}$ Regras e princípios de resolução de problemas ganharão expressão num determinado contexto, independentemente da obediência a objectivos e critérios de âmbito nacional ou sectorial.
} 
heterogéneos, a inserção de novos actores nos processos de decisão e a possibilidade de ajustar sucessivamente, para um dado território, os objectivos acordados e os meios de os alcançar. Quer dizer, um modelo assente em políticas procedimentais, definidoras de quadros de interacção onde a todo o passo se reactive a procura do interesse geral "territorial", capaz de se sobrepor às fracturas ou divergências de partida entre as partes envolvidas. O essencial é a organização de dispositivos territoriais que garantam "interacções organizadas, modos de trabalho em comum, formulação de acordos colectivos. Enquanto a acção pública clássica supõe a concepção prévia do 'interesse geral', a acção procedimental constrói por etapas um 'bem comum' localizado, que assegure a coerência e a legitimidade das decisões" (Lascoumes e Le Bourhis, 1998: 40). ${ }^{30}$ No final, a institucionalização destas novas formas de fazer a política e dos actores colectivos resultantes passará pela valorização dos acordos obtidos, a sua utilização como referência para o futuro e a eventualidade de se "exportar" o interesse comum alcançado para territórios com problemáticas similares.

Em síntese, toda esta compreensão do "local" passa pela sua construção como espaço de concertação, de negociação, de projecto, desaguando numa "concepção do território como construção política fundada em interaç̧ões" (Autès, 2001: 21). O território, tornado "território projecto" pela cooperação dos actores que nele decidem fazer algo em cooperação, restabelecerá assim a essência do político: construir algo em comum. ${ }^{31}$

\section{Desejos e realidades}

O corpo de noções acima exposto arrisca-se a não passar de uma visão estereotipada e programática das coisas, assente em formulações normativas e hipotéticas mais do que analíticas ou extraídas do funcionamento real das práticas políticas. Na verdade, são muitos os trabalhos que mostram a pouca visibilidade dos pressupostos acima esboçados, com amplas referências até a situações nos antípodas do que eles postulam.

\footnotetext{
${ }^{30}$ De um lado, situar-se-ão o pragmatismo das vontades e a maleabilidade dos procedimentos, fazendo com que as particularidades locais dos problemas sejam prioritárias, mas com abertura para a sua evolução ao longo do tempo; do outro, a vertente democrática da livre confrontação de interesses e diálogo de pontos de vista antagónicos, com "estruturas de cooperação sobre a definição das questões locais, os métodos de trabalho e as decisões a tomar” (Lascoumes e Le Bourhis, 1998: 40).

31 A comunicação, a interacção, a negociação entre actores do campo político e conexos produz o território como espaço legítimo da acção pública. Nesse sentido, noções como a proximidade, a eficácia, a participação ou a cidadania são os novos materiais de um referencial político construído à volta do local: "a governance, o contrato, o projecto, tornam-se os novos instrumentos de uma acção pública em recomposição” (Autès, 2001: 22).
} 
Seria exaustivo enumerar tais trabalhos, atentos, entre outras coisas, ao peso das instituições e das resistências à mudança em cada caso, nacional e local. Mas trata-se aqui de dar relevo a esses aspectos, pelo que são deixadas várias considerações de importância que nos parece fundamental.

Pensemos nos dispositivos de avaliação e controlo do governo central sobre as autoridades locais em Inglaterra, nas últimas décadas, os quais, para imporem os méritos da gestão privada aos serviços autárquicos, demoliram grande parte da autonomia local e até a noção de serviço público a partir do território (Le Galès, 2005). Tratou-se dum processo continuado de recentralização de poderes, pautado pelos instrumentos de controlo com que as agências governamentais levaram o new public management às administrações locais, enredando-as num apertado manto burocrático. Ao arrepio de qualquer "governação" negociada, os processos de vigilância contabilística e as auditorias técnicas, a incitação à competição e ao value for money, a medição das performances e a classificação hierarquizada das autarquias, em prol da "empresarialização" dos sectores públicos, não deixaram de criar tensões entre os poderes locais e o Governo. Mantiveram, todavia, a Grã-Bretanha como um dos países mais centralizados da Europa, onde as autoridades locais evidenciam as maiores debilidades. Isto enquanto as prioridades estratégicas dos territórios e as necessidades específicas das populações eram "deixadas de lado em benefício da competição para obter a nota máxima, símbolo do sucesso político e profissional" (Le Galès, 2005: 263)

Por outro lado, quão contraditória é, em França, a territorialização da acção pública, a toda a hora mitigada pelo "retorno do Estado" e das lógicas corporativas de tratamento dos problemas, assim como do controlo pessoal dos eleitos locais sobre os processos concebidos para maior abertura, participação, transparência e articulação supra-municipal das políticas locais. ${ }^{32}$ Num país onde o interesse geral continua a entender-se consubstancial à actuação do Estado, refere Mérieux (2005), a "subsidiariedade" permanece a excepção, sendo difícil conjugar o interesse comum com a atribuição a outros actores que não o Estado de capacidade para produzir a acção pública no âmbito local ou ajustá-la aos contextos territoriais. ${ }^{33}$

\footnotetext{
32 Já Lascoumes e Le Bourhis apontavam para os entraves às práticas deliberativas inerentes à construção do "bem comum" no território. Factores como a manutenção das relações exclusivistas, limitadas a determinados grupos e redes, por parte da classe política local, empenhada na continuidade dos seus poderes através das negociações pontuais, caso a caso, com os actores locais, a quem não proporciona meios ou vontades de formação de acordos gerais e colectivos no território, estão ainda muito presentes.

33 Assinala o autor: "a 'subsidiariedade' continua pensada na forma derrogatória - um sistema de excepções incorporado no dispositivo mesmo da lei - em vez de o ser na forma da 'supletividade', que testemunharia uma vontade do Estado de abrir um espaço de autonomia relativa para a construção de um 'bem comum territorial'” (Mérieux, 2005: 29).
} 
As políticas de contratualização entre governo e autarquias, por exemplo, parecem, aos olhos de muitos, estar a reanimar a centralização e as relações de força desiguais entre o Estado e os poderes locais, constituindo mais uma oportunidade para a imposição das condições do centro aos "parceiros" locais. Sob a aparência de algo negociado entre partes iguais - e particularmente quando se trata das regiões, muito frágeis do ponto de vista político-institucional, apesar das esperanças nelas depositadas (Dupoirier, 1998) -, regressa-se a velhos desequilíbrios, continuando o referencial e os interesses nacionais a comandar as prioridades e os referenciais locais.

Se é assim em França, na generalidade dos países europeus a "cooperação contratual está igualmente dependente dos modos de acção tradicionais do Estado", nota Marcou (1997: 37), que não deixa de enfatizar o papel pouco transparente, cheio de "não ditos" e "implícitos", das contratualizações entre o Estado e autarquias locais francesas. Na realidade, os presidentes destas, conservando a exclusividade da representação territorial junto dos organismos estatais, podem mesmo continuar a desprezar as oposições municipais e as experiências participativas (quando existem) no âmbito das matérias contratadas.

Por conseguinte, o optimismo das noções de "contratualização" ou "governação", sempre pronto a reiterar o pendor democrático das novas parcerias e articulações, é muitas vezes desmentido pelas categorias de dirigentes (eleitos e técnicos) que mais facilmente se associam às elites administrativas, económicas e profissionais do que às populações (Biarez, 1999). Sob a capa da "governação" territorial, abriga-se por norma uma estrutura de decisões onde o económico apenas participa se os ganhos materiais forem avultados e a sua perspectiva dos interesses a dominante, deixando-se as matérias da reivindicação popular e associativa para recursos públicos cada vez mais escassos e incertos. No tocante às políticas participativas, tudo acaba muitas vezes por fazer-se, sobretudo nas metrópoles, em prol das grandes empresas e agências de representação económica (Câmaras de Comércio e Indústria, associações empresariais), não do mundo associativo ou das populações em geral (Lefèvbre, 2005).

Esta é, indubitavelmente, mais uma das matérias em que o contexto manda, com o peso histórico das culturas nacionais a ser decisivo nos resultados obtidos (Heinelt, 2002). Nada assegura, de facto, que a selecção justa e criteriosa dos participantes, a sua mútua confiança e entendimento, os meios materiais necessários, a mudança até na noção de cidadania requerida pelas dinâmicas participativas, encontrem, aqui e ali, acolhimento favorável. São, aliás, muitos os estudos a evidenciar que as organizações de mediação tradicionais (partidos e sindicatos, Igrejas, grupos de interesse) arranjam 
sempre maneira de enquadrar os debates e orientar os processos participativos neste ou naquele sentido. Pior, que essa é, muitas vezes, a única forma de neles se verificar participação digna de registo, quando as camadas populares, inibidas por múltiplas desvantagens, tendem a permanecer ausentes, e a mobilização das classes médias se faz por norma para salvaguardar privilégios do bem-estar individual. ${ }^{34}$ No caso das metrópoles francesas, mais uma vez, os procedimentos de democracia participativa parecem ter vindo consolidar os elementos representativos habituais (Caillosse, 1999), em particular a centralidade dos presidentes da câmara na política local. As necessidades de socialização política e de interiorização de regras de jogo estabelecidas pelos políticos, as assimetrias de informação entre os grupos sociais, o grau de "especialização" requerido por muitos debates, não só afastam os de mais fracos recursos, já de si estigmatizados, como têm conferido aos dirigentes autárquicos a possibilidade de cooptar os "legítimos representantes" da sociedade civil. ${ }^{35}$

Por estas razões, não será surpresa encontrar para a França relatos sobre a opacidade, a confusão, a desarticulação entre níveis de intervenção, a monopolização e personificação do poder, o escamoteamento da democracia participativa e o esvaziamento das assembleias deliberativas, o desprezo pela transparência, a politização dos projectos, o reforço das assimetrias rural/urbano e o "retorno do Estado", que a descentralização pôde despoletar, abrigar ou consagrar. Mabileau (1997) conclui mesmo que em nenhum outro país democrático o poder monopolista dos autarcas e seus satélites está tão consagrado. Designadamente, pelas possibilidades de acesso ao poder central e as regras da "democracia de contacto", a que vieram juntar-se ultimamente estratégias de comunicação e imagem, bem como as prerrogativas de coordenação da multiplicidade de instituições locais criadas, fazendo dos líderes municipais os grandes "mestres do jogo" ${ }^{36}$ Onde Mény (1993) fala duma "república de feudos", outros vêem

\footnotetext{
${ }^{34}$ Toda uma corrente de interpretação insiste "sobre os limites do fenómeno, os efeitos de legitimação de estruturas de poder assimétricas que induz, os conluios entre elites e a cooptação clientelista que o atravessa, as distorções que as desigualdades sociais provocam até nas práticas participativas" (Bacqué et al., 2005: 16).

${ }^{35}$ O que deu azo a autênticos profissionais da mediação e da participação (Jouve, 2005), novos notáveis sacralizados a nível local pelas competências, cognitivas e instrumentais, que conseguem mobilizar e os transportam para a órbita do poder autárquico. A criação dos "Conselhos de Desenvolvimento" nas aglomerações de mais de 50.000 habitantes pela Lei Voynet ( $\mathrm{n}^{\circ}$ 99-533 de 25 de Junho de 1999) terá participado desta "confiscação do debate público pelos notáveis locais" (ibid.).

${ }^{36}$ Com a descentralização, o modelo "maioral" ter-se-á reforçado, dando ao chefe do executivo "uma preeminência sem paralelo, que retira da confusão dos poderes territoriais (ele é simultaneamente chefe da administração e presidente da assembleia) e da fraqueza geral dos partidos polí-
} 
o efeito contraditório da descentralização e da "perversão da democracia local", nessa ordem de novos senhores feudais tão consagrada na França descentralizada (Hureaux, 2004).

Análise que a outros países do "Sul", com toda a evidência, servirá de forma exemplar, a confirmar-se que os sistemas de administração local dos países do Sul da Europa pouco aderiram ao new public management e se mantêm fiéis a funcionamentos mais clássicos (John, 2001). Em Portugal, sabemo-lo, são fracos os avanços na descentralização. Falhada a regionalização e a instituição de efectivas instituições metropolitanas, a periferia continua subordinada ao "paradigma da centralização contínua e interminável” (Monteiro, 1996: 22). No entanto, pontos de semelhança com o diagnóstico acima traçado são inegáveis. Quer porque qualquer veleidade de organização no âmbito territorial se mantém na estrita dependência (política, administrativa, "estratégica", financeira) do centro, quer porque, numa democracia de acessos, marcada do mesmo modo pela concentração do poder nas chefias autárquicas, se continua a prover à ligação entre o centro e os territórios por vias mais pessoalizadas, onde a influência das assembleias eleitas ou de grupos social e politicamente heterogéneos é residual. O privilégio vai para a rede de colaboradores do líder municipal, com as instituições ou opiniões de carácter mais público a serem postas em segundo plano, não raro hostilizadas (Ruivo e Francisco, 1998/1999). De resto, num tecido social dominado pelas formas privadas de interacção, é a longevidade dos autarcas no poder que assegura as formas de integração e as continuidades tidas por necessárias, não qualquer cultura "territorial" de apreensão dos problemas, gestão de projectos ou procura do bem comum a partir de quadros multi-participados de acção colectiva. ${ }^{37}$ As cooperações procuradas, as mobilizações "pertinentes", as lógicas de confiança, de "estratégia" e identidade locais investidas, os atributos do "capital social" enfim, presentes noções de "governação" ou de "projecto", terão de ver-se mais como apanágio, e património, de certas lideranças - de preferência, as de autarcas com ligações favorecidas a diferentes sectores ou serviços do Estado, mormente os desconcentrados ou periféricos -, à volta das quais se organizam

ticos a nível local" (Nay, 2003: 213). A burocratização das grandes autarquias francesas e a sua dotação em poderes técnicos acentuará, paradoxalmente, a "monarquização" do poder local, ficando para as assembleias eleitas um papel de câmaras de eco: "o trabalho de construção da agenda pública permanece na prática controlado pelo patrão, que se apoia, para governar, numa retaguarda dirigente, constituída por alguns homens e mulheres unidos pela lealdade política, segredos de alcova e regras de trabalho fortemente informais" (ibid.).

37 A posição recentemente tomada pela Associação Nacional de Municípios perante a possibilidade da limitação da duração dos mandatos autárquicos é sintomática da importância que a longevidade política dos autarcas tem no seu ascendente sobre o espaço local. 
redes relacionais empenhadas no usufruto das oportunidades oferecidas pelas políticas públicas. Não fará então muito sentido procurar, nos universos locais em Portugal, a eficácia institucional e a acção estratégica que a história, a cultura, a economia global ou a descentralização terão impulsionado noutros contextos, sob a forma de relações de cooperação e actuação conjunta entre vários sectores da sociedade.

Para o caso português, é até apreciável a distanciação das elites autárquicas relativamente à estrutura social e aos "parceiros" sociais, em geral, tal como o esvaziamento dos órgãos consultivos eleitos, tornando-se a função presidencial fechada sobre si mesma e o grupo das afinidades presidenciais. $\mathrm{Na}$ prática, devido às funções de interlocutor privilegiado com o Estado, numa sociedade cuja dependência dos contextos, significados e consensos estabelecidos por este a integração europeia reforçou (Reis, 2004), ${ }^{38} \mathrm{o}$ eleito local é, não só a pedra angular de qualquer "governação territorial”, mas um dos principais óbices à sua evolução.

Torna-se, por isso, irrealista pensar que as dificuldades conhecidas da sociedade portuguesa na organização autónoma de interesses podem ser superadas a partir da realidade local, sem que o Estado estabeleça, e as lideranças locais aceitem, os parâmetros de actuação relevantes. Na verdade, no espaço local a regra é a "relativa ausência de dinâmica conjunta" (Mozzicafreddo et al., 1991: 146), correlativa de uma suposta cultura de passividade dos munícipes perante a política local (Rocha, 1989) e do facto de a equipa presidencial se instalar no cerne dos interesses, não tanto estratégias, ${ }^{39}$ orientadores do desenvolvimento local. O que contribui, à sua escala, para essa peculiaridade da sociedade portuguesa que Boaventura de Sousa Santos (2003) designa como a "ausência de projecto", tal como para a deriva "localista" de qualquer tentativa de racionalização supra-municipal, metropolitana ou regional da malha administrativa. É que as solidariedades horizontais que a "governação" por projectos ou lógicas "funcionais" deveria trazer aos espaços locais são combatidas pelo tipo de relacionamento com uma administração central que tolera e promove, além da atomização negocial, a ideia de que os benefícios conseguidos por um município podem sê-lo a expensas dos pares ou vizinhos. ${ }^{40}$

\footnotetext{
${ }^{38} \mathrm{O}$ acesso aos fundos comunitários cristalizou dependências funcionais e relacionais antigas, com a modernização baseada nas políticas comunitárias a acentuar a centralidade do Estado e das suas políticas.

${ }^{39}$ O Poder Local viverá num "vazio estratégico", que o torna vulnerável às pressões avulsas dos empresários locais e lhe retira muitas vezes alcance à intervenção na esfera económica (Mozzicafreddo et al., 1991: 112).

${ }^{40}$ Nuno Portas (1988: 68) referia-se a esta situação como sendo "a pior das possíveis. Fala-se como se se tivesse uma autonomia que se não exerce e mendiga-se, pagam-se lobbies ou procura-se ser
} 
Além do mais, as dificuldades do associativismo inter-municipal, que funcionará apenas para entendimentos pontuais, objectivos pouco ambiciosos ou finalidades político-partidárias de pressão (Portas,1988: 64), revelam outra faceta da sociedade portuguesa: a forte segmentação sócio-territorial (Medeiros,1988). Tal faz com que às ligações metropolitanas ou interregionais possam responder princípios de exclusão e de oposição baseados em diferenças culturais-regionais. Donde, as diferenciações sócio-territoriais segmentárias (bairrismo, patriotismo local, guerras de campanários, segregações sociais inscritas nas diferenças de habitat), tendem a sobrepor-se às modalidades de cooperação ou de associação, produzindo espaços regionais que pouco mais serão do que justaposições de racionalidades ego-centradas e eleitoralismos particulares. Falar de cultura ou consciência de acção colectiva territoriais nestas circunstâncias é ousado. Até porque o Estado, ao centrar a vida política nos distritos - entidades com pouco relevo territorial e socioeconómico, mas funcionais para a acção política -, ajuda ao bloqueamento da racionalidade territorial e à hipertrofia da racionalidade político-eleitoral (Reis, 1998).

Em suma, dominados por lógicas atomísticas, com fraco historial de trabalho em conjunto ou noção de destino partilhado, os poderes locais perpetuam uma mundivisão que consolida a fragmentação e a concorrência individualista no território, de que o Estado se tem servido para manter a sua própria centralidade e desvalorizar intentos de organização territorial mais avançada. Desta maneira, também Portugal evidenciará um modelo "estadista" de governança (Kohler-Koch e Eising, 1999), que, por um lado, activa, de forma parcelar e controlada, a integração dos poderes locais nas políticas públicas e, por outro lado, alimenta a apropriação patrimonial, personalizada e privatística da autoridade nos municípios, dissipando as tentativas de "governação" territorial propriamente dita. Para mais, à centralização do Estado e ao fechamento das elites autárquicas sobre si próprias, numa sociedade territorialmente fragmentada e acantonada à tutela do Estado, não subjaz propriamente uma "cultura cívica" de base (Almond e Verba, 1963; Putnam, 1993) que leve as lideranças locais a inserir-se ou a coordenar tecidos de solidariedades alargadas. O co-envolvimento de poderes, interesses e grupos sociais heterogé-

mais esperto que o vizinho para obter mais. Do lado do Governo, mexem-se os cordéis que interessa, apoia-se quem se prefere ou quem se mexe antes, não se publicam os mapas do poder discricionário e elogia-se o Poder Local pela sua compreensão dos problemas e óptima colaboração". A este propósito, um presidente de Câmara da área metropolitana do Porto referia, há uns anos, eloquentemente, "o que puder tirar aos outros para melhorar o meu concelho, desde que seja por meios lícitos, vou tirar” (Diário de Notícias, 9/10/2003). 
neos em estratégias territoriais, guiadas por lógicas de "projecto" ou propósitos de construção de um "bem comum" no território, só pode ser considerado longínquo.

Finalmente, quanto às mudanças "territorializadoras" induzidas pela construção europeia, novamente se verifica que as diferenças de cada contexto nacional-local permanecem fundamentais, sobrepondo-se a eventuais generalizações a partir da variável europeia (Boisseaux, 2005). Isto é, as oportunidades oferecidas pela Europa aos territórios têm de ser vistas à luz das configurações institucionais e relacionais específicas que as abordam, o que mostra funcionamentos assaz distintos de país para país. Apesar da "eurocompatibilidade" que se atribui às instâncias territoriais, trata-se em muitos casos de uma mera "eurocompatibilidade de fachada" (Boisseaux, 2005). Muitas vezes, nota Mathiot (1998: 88), o que se faz é uma espécie de "aculturação europeia", "que parece menos a constituição ou a fabricação de um novo sistema de acção do que a incorporação no sistema existente daquilo que 'é preciso de Europa' para surgir em Bruxelas como parceiro fiável e por isso susceptível de ser ajudado" (ibid.: 88).

Isto para dizer que aqueles que se inserem nas políticas comunitárias de forma dinâmica, que não se inibem de ir aconselhar-se a Bruxelas, achando que as regras comunitárias são positivas e "compreensíveis", e que se distanciam, no seu afã europeu, das respectivas administrações nacionais, pouco recorrendo à sua ajuda, são a excepção (Klausen e Goldsmith, 1997). $\mathrm{Na}$ maioria dos casos, as políticas comunitárias consolidam o papel das redes político-administrativas existentes, sem que surjam formas assinaláveis de protesto vindas dos territórios.

A "europeização", portanto, não só está longe de impor uma nova situação constitucional aos países membros da União (Kholer-Koch, 1998: 53), como essa característica de potenciar os actores territoriais e levá-los a intervir directamente nas políticas públicas é incerta. Não sendo de desprezar os efeitos da europeização nos princípios e formas de governar a nível nacional (Radaelli, 2000), é preciso saber que nada predispõe a Comissão, por exemplo, a interferir nas redes que nesse âmbito organizam as políticas públicas, nem a fazer qualquer coisa que, de alguma forma, levante desconfianças nos Estados-membros. Até porque "precisa dos Estados, e está mais interessada na eficácia política e na eficiência das medidas do que em questões mais amplas de reestruturação política" (Keating e Pintarits, 1998: 41). Quando muito, os princípios directores, as práticas e regras suscitados pela Comunidade Europeia serão uma "oferta" ligada às transferências financeiras. Isto é, modalidades propostas às equipas territoriais para se relacionarem com a Comissão, conceitos e estratégias para melhorar a competiti- 
vidade e as capacidades de desenvolvimento dos seus espaços. Trata-se, todavia, apenas de "uma janela de oportunidade, uma oferta que a cada caso encontra ou não a procura dos actores individuais" (ibid.: 41). Só uma análise in fine permitirá ver em que medida a "embalagem ideológica" com que a União Europeia reveste os seus programas influencia a evolução institucional dos Estados-membros. Mormente, em direcção a uma maior territorialização das respectivas políticas e ao incremento de sistemas propriamente territoriais de decisão e acção públicas.

\section{Conclusão}

Negar as mudanças nas maneiras de fazer a política e de gerir a vida colectiva com a crise do Estado e os processos da sua descentralização, a construção europeia e os fenómenos da globalização, é contrariar evidências e pressupor, de alguma forma, a inércia como regra no mundo social. No entanto, se conceitos como "governação" territorial ou perspectivas como a da territorialização da acção pública, apresentados na sequência daqueles factores, têm de ser levados a sério, a transformação ampla das concepções e práticas políticas que tais conceptualizações pretendem significar deve ser relativizada. Porque os novos consensos e modos de fazer que a "governação" e os "territórios" trarão estão longe de ser adquiridos. No âmbito da acção pública territorial, tudo parece ainda eivado de fundamentos antigos, na forma de saberes, permanências operacionais e automatismos de comportamento de que não se consegue ou se deseja fugir. Mudanças de escala não podem aqui ser tomadas por mudanças na substância dos fenómenos, como se os formatos e normas da acção pública estivessem agora em perfeita ruptura com o passado. Pensar os territórios (locais, metropolitanos, regionais) enquanto fonte revitalizada de acção colectiva e berço de coligações "estratégicas" - libertas da tutela estatal, apostadas na promoção de identidades territoriais, animadas por "projectos", "parcerias" ou agendas sufragadas pelos cidadãos - é ainda ver a realidade pelo prisma do desejo. Nas interdependências crescentes que definem hoje as instituições e a gestão das políticas públicas, haverá sem dúvida efeitos de "territorialidade" com alcance para mudar os símbolos, as crenças, as narrativas, as relações de força e a operacionalidade da acção pública. No entanto, tudo convida a precaução nos juízos. Os modelos de regulação e distribuição dos governos e tradições nacionais não desapareceram. De resto, mau grado a popularidade de noções como a de "autarquias-providência", o "local" não substitui a cidadania (Schnapper, 1994), nem a cultura localista, clientelar, fechada e individualista dos poderes autárquicos deixou de manifestar-se (Mény, 1994). Por outro lado, os corpos profissionais e os interesses dos 
agentes económicos não se moldam facilmente às exigências de coerência, transversalidade e identidade nos territórios, privilegiando mais as suas lógicas "extraterritoriais" de actuação. A acção estratégica territorial, na verdade, surge fortemente mitigada pelas dificuldades de tecer alinhamentos duradouros nos territórios, dadas as descontinuidades, incongruências, dissonâncias, temporalidades específicas dos projectos dos indivíduos, organizações e das próprias políticas públicas.

Daí que, não descurando o mimetismo institucional e o sentido de boas práticas que, um pouco por todo o lado, decorrem dos valores da proximidade, das parcerias e sinergias com a sociedade civil, das identidades, governação, consenso e pragmatismo, da qualidade e desenvolvimento durável, da transparência e participação - entre outras referências que conferem aos actores e contextos territoriais primazia na acção pública -, seja forçoso constatar que as redes envolvidas nestas lógicas têm ainda uma tendência grande para reproduzir o "idêntico". Isto é, que o "antigo" e o "novo" andam lado a lado sem grandes estorvos. Que nem o clientelismo desapareceu, nem as redes se tornaram mais transparentes porque "localizadas" (se efectivamente "localizadas"), nem a velha "regulação cruzada" se evaporou. Ou seja, os actores ainda se apoiam, numa grande parte, nas convicções e modos de actuar com que se familiarizaram. Não surpreenderá, por isso, deparar com situações onde o que existe de "territorial" é simultaneamente Estado, ou Estado por outras vias, tal como com situações onde as especificidades territoriais são basicamente conferidas por certos sectores socioeconómicos.

Tudo tem assim de ser equacionado a partir da pesquisa empírica necessária para dar conta do que está em causa. Quando muito, poderá falar-se da transição de modelos mais centralizados, hierárquicos e tecnocratas do progresso para novas metodologias plasmadas no território, de que a Europa, o desenvolvimento durável, a democracia, a cidadania em geral, necessitam. Nada parece, no entanto, garantido, continuando a realidade dos factos a temperar os entusiasmos com a sua matriz complexa de permanências e inovações.

\section{Referências bibliográficas}

Almond, Gabriel; Verba, Sidney (1963), The Civic Culture: Political Attitudes and Democracy in Five Nations. Princeton: Princeton UP.

Ascher, François; Godard, Francis (1999), "Vers une troisième solidarité", Esprit, 11, 168-189.

Autès, Michel (2001), "Les politiques publiques locales", in Les Nouvelles Politiques locales - Cahiers lillois d'économie et de sociologie. Paris: L'Harmattan, 7-23. 
Bayart, Jean-François (1985), "L'énonciation du politique”, Revue Française de Science Politique, 35(3), 343-373.

Benko, Georges; Lipietz, Alain (orgs.) (1994), “As regiões ganhadoras', Distritos e redes os novos paradigmas da geografia económica. Oeiras: Celta.

Bacqué, Marie-Hélène et al. (2005), "Éditorial”, Espaces et Sociétés, 123(4), 9-19.

Biarez, Sylvie (1999), "Incertitudes et caractère composite des gouvernements locaux en Europe”, in Richard Balme; Alain Faure; Albert Mabileau, Les Nouvelles Politiques Locales. Paris: Presses de Sciences Po, 39-56.

Boisseaux, Stéphane (2005), “Introduction - Terriotires incertains: l'Europe en filigrane”, in Alain Faure; Anne-Cécille Douillet, L'action publique et la question territoriale. Grenoble: PUG.

Bouinot, Jean; Bermills, Bruno (1995), La gestion stratégique des villes: entre compétition et cooperation. Paris: Armand Colin.

Caillosse, Jacques (1999), "Éléments pour un bilan juridique de la démocratie locale en France”, in Loïc Blondiaux et al., La démocratie locale. Représentation, participation et espace public. Paris: PUF, 63-78.

Calame, Pierre; Talmant, André (1997), L'État au coeur. Le mécano de la gouvernance. Paris: Desclée de Brouwer.

Cefaï, Daniel (2001), Cultures politiques. Paris: PUF.

Chevallier, Jacques (1978), "Le modele centre/périphérie dans l'analyse politique", in Centre, Périphérie, Territoire, CURAPP. Paris: PUF.

Cohen, Michael D.; March, James G.; Olsen, Johan. O. (1972), “A Garbage Can Model of Organizational Choice, Administrative Science Quarterly, 17(1), 1-25.

Cooke, Phil (1997), "Institutional Reflexibility and the Rise of the Region State", in Georges Benko; Ulf Strohmayer, Space \& Social Theory. London: Blackwell.

Demeestere, R; Padioleau, J.G (1992), “Les démarches stratégiques de planification des villes”, Annales de la Recherche Urbaine, 51, 28-39.

Donzelot, Jacques; Estèbe, Philippe (1994), L'État animateur. Essai sur la politique de la ville. Paris: Ed. Esprit.

Dubet, François (2002), Le déclin de l'institution. Paris: Seuil.

Dupoirier, Elisabeth (org.) (1998), Régions, la croisée des chemins. Perspectives françaises et enjeux européens. Paris: Presses de Sciences Po.

Duran, Patrice; Thoenig, Jean-Claude (1996), "L'État et la gestion publique territoriale”, Revue Française de Science Politique, 46(4), 580-623.

Duran, Patrice (1999), Penser l'action publique. Paris: L.G.D.J.

Ehrenberg, Alain (2000), La fatigue d'être soi. Dépression et société. Paris: Odile Jacob.

Friedberg, Erhard, (1993), Le pouvoir et la règle. Paris: Seuil.

Gaudin, Jean-Pierre (1995), "Politiques urbaines et négociations territoriales, quelle légitimité pour les réseaux de politiques publiques?”, Revue Française de Science Politique, 45(1), 31-56. 
Gaudin, Jean-Pierre (1999), Gouverner par contrat. L'action publique en question. Paris: Presses de Sciences Po.

Grémion, Pierre (1977), Le pouvoir périphérique: bureaucrates et notables dans le système politique français. Paris: Seuil.

Hall, Peter A.; Taylor, Rosemary C.R. (1997), "La science politique et les trois néoinstitutionnalismes", Revue Française de Science Politique, 47(3-4), 469-496.

Harding, Alan (1993), "Gouvernance locale' et réaménagement urbain: pour un programme d'analyse comparative”, in Sylvie Biarez; Jean-Yves Nevers (orgs.), Gouvernement local et politiques urbaines. Actes du Colloque International, Grenoble 2-3 février. Grenoble: Ed. CERAT, 475-494.

Harvey, David (1992), "Social Justice, Postmodernism and the City", International Journal of Urban and Regional Research, 16, 588-601.

Healey, Patsy et al. (orgs.) (1997), Making Strategic Spatial Plans. Innovations in Europe. London: UCL.

Heinelt, Hubert (2002), "Achieving Sustainable and Innovative Policies through Participatory Governance in a Multi-level Context", in Hubert Heinelt et al. (orgs.), Participatory Governance in Multi-level Context. Concepts and Experience. Opladen: Leske+Budrich, 17-32.

Hunter, Floyd (1953), Community Power Structure. A Study of Decision Makers. Chapell Hill: University of North Carolina Press.

Hureaux, Roland (2004), Les nouveaux féodaux. Le contresens de la décentralisation. Paris: Gallimard.

Ingallina, Patrizia (2001), Le projet urbain. Paris: PUF.

Inglehart, Ronald (1993), La transition culturelle dans les sociétés industrielles avancées. Paris: Economica.

Jefferey, Charlie (org.) (1997), The Regional Dimension of the European Union: Towards a Third Level in Europe? London: Frank Cass.

Jessop, Bob (1994), “The Regulation Approach, Governance and Post-fordism: Alternative Perspectives on Economic and Political Change?”, in Ash Amin (org.), Post-Fordism. A Reader. Oxford: Blackwell.

John, Peter (2001), Local Governance in Western Europe. London: Sage.

Jouve, Bernard (1995), "Réseaux et communautés de politique publique en action", in Patrick Le Galès; Mark Thatcher (orgs.), Les réseaux de politique publique. Débat autour des policy networks. Paris: L'Harmattan, 121-139.

Jouve, Bernard; Lefèvre, Christian (1999), "De la gouvernance urbaine au gouvernement des villes? Permanence ou recomposition des cadres de l'action publique en Europe", Revue Française de Science Politique, 49(6), 835-853.

Jouve, Bernard (2005), "La démocratie en métropoles: gouvernance, participation et cytoyenneté”, Revue Française de Science Politique, 55(2), 317-337.

Keating, Michael; Pintarits, Sylvia (1998), "Europe and the Regions: Past, Present, and Future”, Comparative Social Research, 17, 33-63. 
Keating, Michael (1998), The New Regionalism in Western Europe. Aldershot: Edward Elgar.

Kholer-Koch, Beate (1998), "La renaissance de la dimension territoriale en Europe: entre illusion et réalité, in Emmanuel Négrier; Bernard Jouve (orgs.), Que gouvernent les régions d'Europe? Échanges politiques et mobilisations régionales. Paris: L'Harmattan.

Kholer-Koch, Beate; Eising, Rainer (1999), The Transformation of Governance in the European Union. London: Routledge.

Klausen, Kurt K.; Goldsmith, Michael (orgs.) (1997), European Integration and Local Government. Cheltenham: Edward Elgar.

Kooiman, Jan (org.) (1993), Modern Governance. London: Sage.

Lacour, Claude (1996), "La tectonique des territoires: d'une métaphore à une théorisation”, in Bernard Pecqueur (org.), Dynamiques territoriales et mutations économiques. Paris: L'Harmattan, 25-48.

Lascoumes, Pierre; Le Bourhis, Jean-Pierre (1998), "Le bien commun comme construit territorial. Identités d'action et procedures”, Politix, 42, 37-66.

Lascoumes, Pierre; Le Galès, Patrick (orgs.) (2005), Gouverner par les instruments. Paris: Presses de Sciences Po.

Le Galès, Patrick (1998), "Régulation, gouvernance et territoire”, in Jacques Commaille; Bruno Jobert, Les Métamorphoses de la Régulation Politique. Paris: L.G.D.J., 203-240.

Le Galès, Patrick (2005), “Contrôle et surveillance. La restructuration de l'État en Grande-Bretagne”, in Lascoumes; Le Galès (orgs.), 237-267.

Leca, Jean (1994), "L'État creux”, in Bertrand Badie et al., La France au-delà du siècle. Paris: L'Aube, 91-103.

Lefevbre, Rémi (2001), "Rhétorique de la proximité et 'crise de la représentation'”, in Cahiers lillois d'économie et de sociologie - Les nouvelles politiques locales, 35-36, 111-132.

Lefèvre, Christian (2005), "Faire des métropoles des territories démocratiques”, Pouvoirs Locaux, 65.

Leresche, Jean-Philippe (org.) (2001), Gouvernance locale, coopération et légitimité. Le cas suisse dans une perspective comparée. Paris: Pedone.

Lindblom, Charles E. (1959), “The Science of Muddling Through”, Public Administration Review, XIX, 79-88.

Logan, John; Molotoch, Harvey (1987), Urban Fortunes. The Political Economy of Space. Berkeley: University of California Press.

Lorrain, Dominique (1995), "Introduction - l'extension du marché”, in Dominique Lorrain; Gerry Stoker (orgs.), La privatisation des services urbains en Europe. Paris: La Découverte, 9-30.

Lorrain, Dominique (2000), "Gouverner les villes. Questions pour an agenda de recherche”, Pôle Sud, 13, 27-40. 
Lorrain, Dominique (2005), "Les pilotes invisibles de l'action publique, le désarroi du politique?”, in Lascomes; Le Galès, 163-195.

Luhmann, Niklas (1999), Politique et complexité. Paris: Cerf.

Mabileau, Albert (1997), "Les génies invisibles du local. Faux-semblants et dynamiques de la décentralisation”, Revue Française de Science Politique, 47(3-4), 340-376.

Marcou, Gérard; Rangeon, François; Thiébault, Jean-Louis (1997), La coopération contractuelle et le gouvernement des villes. Paris: L'Harmattan.

Marcou, Gérard (1997), "Introduction”, in Marcou et al., 7-41.

Massardier, Gilles (2003), Politiques et action publique. Paris: Armand Colin.

Mathiot, Pierre (1998), "Les effets de la gestion de dispositifs communautaires sur les acteurs et les systèmes d'action nationaux. L'exemple de l'Objectif 3 du Fonds Social Européen”, Politix, 43, 79-91.

Mayntz, Renate (1993), "Government Failures and the Problem of Governability: Some Comments on a Theoretical Paradigm", in Jan Kooiman (org.), Modern Governance. London: Sage, 9-20.

Medeiros, Fernando (1988), "Um sistema social de espaços múltiplos - a autonomia do local na sociedade portuguesa”, Revista Crítica de Ciências Sociais, 25/26, 143-162.

Mény, Yves (1992), "La république des fiefs", Pouvoirs, 60.

Mény, Yves (1994), “L’indispensable mutation des politiques territoriales”, in Bertrand Badie et al., La France au-delà du siècle. Paris: L'Aube, 137-144.

Mérieux, Olivier (2005), "Introduction - Le débordement territorial des politiques sectorielles", in Alain Faure; Anne-Cécille Douillet (orgs.), L'action publique et la question territoriale. Grenoble: PUG, 27-32.

Monteiro, Nuno Gonçalo (1995), “Os poderes locais no Antigo Regime”, in César de Oliveira (org.), História dos municípios e do poder local. Dos finais da Idade Média à União Europeia. Lisboa: Círculo de Leitores, 17-175.

Mozzicafreddo, Juan et al. (1991), Gestão e legitimidade no sistema político local. Lisboa: Escher.

Nay, Olivier (2003), "La politique des bons offices. L'élu, l'action publique et le territoire”, in Jacques Jacques (org.), La politisation. Paris: Belin, 199-219.

Négrier, Emmanuel; Jouve, Bernard (orgs.) (1998), Que gouvernent les régions d'Europe? Échanges politiques et mobilisations régionales. Paris: L'Harmattan.

Novarina, Gilles (1997), "Les réseaux de politique urbaine. Concurrences et coopérations entre acteurs”, in François Godard (org.), Le gouvernement des villes. Territoire et pouvoir. Paris: Descartes \& Cie, 213-254.

Papadopoulos, Yannis (1995), Complexité sociale et politiques publiques. Paris: Montchrestien.

Pasquier, Romain (2004), La capacité politique des régions. Une comparaison Francel Espagne. Rennes: PUR.

Pecqueur, Bernard (2000), Le développement local. Paris: Syros. 
Pickvance, Chris; Préteicelle, Edmond (orgs.) (1995), State Restructuring and Local Power. London: Pinter.

Pinson, Gilles; Vion, Antoine (2000), "L'internationalisation des villes comme objet d'expertise”, Pôle Sud, 13, 85-102.

Pinson, Gilles (2002), “Des villes et des projets. Changement dans l'action publique et institutionnalisation de nouveaux territories politiques”, in Joseph Fontaine; Patrick Hassenteufel, To Change or Not to Change. Les changements de l'action publique à l'épreuve du terrain. Rennes: PUR, 233-254.

Pinson, Gilles (2005), "Le projet urbain comme instrument d'action publique", in Lascoumes; Le Galès (orgs.), 199-233.

Poggi, Gianfranco (1996), “La nature changeante de l'État. L'État et quelques aspects de son histoire”, in Vincent Wright; Sabino Cassese (orgs.), La récomposition de l'État en Europe. Paris: La Découverte, 19-35.

Pongy, Mireille (1997), "Gouvernance et citoyenneté, la différenciation du politique”, in Guy Saez et al. (orgs.), Gouvernance métropolitaine et transfrontalière. Paris: L'Harmattan.

Portas, Nuno (1988), "Sobre alguns problemas da descentralização”, Revista Crítica de Ciências Sociais, 25/26, 61-78.

Putnam, Robert D. (1993), Making Democracy Work. Civic Traditions in Modern Italy. Princeton: Princeton UP.

Radaelli, Claudio M. (2001), "The Domestic Impact of European Union Public Policy: Notes on Concepts, Methods, and the Challenge of Empirical Research", Politique Européenne, 5(3), 107-142.

Reis, José (1998), “O que é o território?”, Expresso, Fevereiro de 1998.

Reis, José (2004), "Estado, mercado e comunidade”, Revista Crítica de Ciências Sociais, 70, 81-100.

Reis, José (2006), “Uma epistemologia do território”, in Ensaios de Homenagem a António Simões Lopes. Lisboa: Instituto Superior de Economia e Gestão, 353-366.

Rhodes, R. A. W. (1997), Understanding Governance. Policy Networks, Governance, Reflexibility and Accountability. Buckingham: Open University Press.

Rocha, J. A. Oliveira (1989), "Governo local e cultura política: o caso da Póvoa do Lanhoso”, Sociedade e Território, 9, 108-112.

Rouban, Luc (1999), "Introduction - Citizens and the New Governance”, in Luc Rouban (org.), Citizens and the New Governance. Beyond New Public Management. Ohmsha: IOS Press, 1-5.

Ruivo, Fernando (1993), "Estado e poder relacional: a intervenção informal dos poderes locais em Portugal”, in Boaventura de Sousa Santos (org.), Portugal: Um retrato singular. Porto: Afrontamento.

Ruivo, Fernando (2000a), O Estado Labirintico. O poder relacional entre poderes local e central em Portugal. Porto: Afrontamento. 
Ruivo, Fernando (2000b), Poder local e exclusão social. Coimbra: Quarteto.

Ruivo; Fernando; Francisco, Daniel (1998/1999), "O poder local entre centro e periferias”, Revista Crítica de Ciências Sociais, 52/53, 281-306.

Saez, Guy (1997), "Les politiques publiques comme systèmes de coopération. Une lecture de l'approche conventionnaliste à travers H.S. Becker (et quelques autres...)", in Jean-Pierre Gaudin; Gilles Novarina, Politiques publiques et négociation. Multipolarités, flexibilités, biérarchies. Quelques courants contemporains de recherche. Paris: CNRS Éditions, 19-43.

Santos, Boaventura de Sousa (2003), “Bloqueio em movimento?”, Visão, Especial 10 anos, 22 de Abril.

Santos, Boaventura de Sousa (2005), “A crítica da governação neoliberal: O Fórum Social Mundial como política e legalidade cosmopolita subalterna", Revista Crítica de Ciências Sociais, 72, 7-44.

Schnapper, Dominique (1994), La communauté des citoyens. Sur l'idée moderne de nation. Paris: Gallimard.

Schnapper, Dominique (1994), "Le local ne remplace pas la citoyenneté", in Bertrand Badie et al., La France au-delà du Siècle. Paris: L’Aube, 177-185.

Smith, Andy; Sorbets, Claude (orgs.) (2003), Le leadership politique et le territoire. Les cadres d'analyse em débat. Rennes: PUR.

Stoker, Gerry (1998), “Cinq propositions pour une théorie de la gouvernance”, Revue Internationale des Sciences Sociales, 155, 19-30.

Stoker, Gerry (org.) (1999), The New Management of British Local Governance. Basingstoke: Macmillan.

Stone, Clarence S. (1989), Regime Politics: Governing Atlanta (1946-1988). Lawrence: Kansas UP.

Streeck, Wolfgang; Schmitter, Phillipe C. (orgs.) (1985), Private Interest Government. London: Sage. 